On 3 May Barrie Pittock from the Commonwealth Scientific and Research Organization (CSRO), Australia, visited headquarters to discuss activities of the Australian branch of the Royal Meteorological Society with Executive Director Kenneth C. Spengler. The visit also afforded an opportunity to brief Pittock concerning other AMS activities of interest, particularly plans for the First Conference on Southern Hemisphere Meteorology, scheduled 31 July-6 August 1983 in Sao José dos Campos, Brazil.

Spengler was in Washington, D.C., on 6 May for an American Association for the Advancement of Science meeting of affiliated societies interested in popularization of science through radio and television.

On 7 May Robert Humphries from the Alberta Research Council was at headquarters to discuss with Spengler and Assistant to the Executive Director Evelyn Mazur plans for the 21 st Conference on Radar Meteorology, to be held in Edmonton in September 1983.

On 8 May Spengler and Mazur lef $t$ for The Hague, The Netherlands, to meet with the organizing committee the day before the First International Conference on Meteorology and Air/Sea Interaction of the Coastal Zone, 10-14 May (co-sponsored by AMS and the Royal Netherlands Meteorological Institute). Included in the conference program was the awards ceremony of the Royal Netherlands Academy of Arts and Sciences; the Buys Ballot Medal was presented to A. C. Wiin-Nielsen, Secretary-General of the World Meteorological Organization. After returning to the office on 15 May, Spengler flew to Washington, D.C., on 18 May for the Joint Annual Meeting of the Scientific Manpower Commission and Engineering Manpower Commission. While there he met wi th AMS Past Presidents Robert White, Werner Baum, and David Johnson on Meteorological and Geoastrophysical Abstracts matters.

On 19 May William Reifsnyder from the Yale University School of Forestry and Environmental Studies was at headquarters for discussions with Spengler on proposed activities and plans for the Task Force Forest Meteorology relating to forest canopy-atmosphere interactions.

On 23 and 24 May, Spengler was in Montreal representing the Council of Engineering and Scientific Society Executives at a meeting of the Convention Liaison Council.

On 24 May Meeting Coordinators Evelyn Mazur and Twila Bombard travelled to Williamsburg, Va., to handle arrangements and registration for the AMS/American Geophysical Union/National Aeronautics and Space Administration Symposium on the Composition of Nonurban Troposphere.

Spengler and Mazur travelled to Ottawa, Canada, on the 27 th to attend the meeting and annual dinner of the Canadian Meteorological and Oceanographic Society (CMOS) congress. On 28 May they met with officers and representatives of CMOS on plans for the Fif th Symposium on Meteorological Observation and Instrumentation, to be co-sponsored by AMS and CMOS, to be held in Toronto, April 1983.

On 27 May Peter Kraght and James Green, former Chief Meteorologists for American Airlines, visited headquart ers.

Visitors to headquarters during May included: Deidra McMillin, Hyatt Regency Savannah, Savannah, Ga.; Ted Michalak, The Mority Co.; James Sims, National Weather Service, Boston; Jeff Hill, Reprographics, Boston; Daniel Morrissey, PAR Inc., Concord, N.H.; Paul Brown, Drake Hotel, Chicago; Harold Perreira and Joe Heffernan, Heffernan Press; Buffy Casey and Shawn Lanham, Compugraphics; John Wilson, Stone \& Webster, Boston; Robert Miller, WSI Corp., Bedford, Maine; Fred Sanders, WMAQ, Chicago; J.J. Riordan, American Airlines; Edward J. Cummiskey, Providence, R.l.; Robert Paine, Environmental Research and Technology, Inc.; Phillip I. Youngblood, Conoco, Inc; Kenzo Fujimoto, Harvard School of Public Health; and Lydia Rizzo, Tufts University, with Thomas E. West, Savin Copiers.

\section{Deadlines Calendar}

Fellowships, grants, etc.

15 June 1983

Macelwane Annual Award (this issue, p. 746)

15 June 1983

Hanks and Orville Scholarships (this issue, p. 746)

Call for papers

15 November 19821983 Summer Computer Simulation Conference

(March 1982 Bulletin, p. 272)

26 November 1982 Second International Meeting on Statistical Climatology

(February 1982 Bulletin, p. 160)

Call for nominations

31 December 1982 Alan T. Waterman Award (July 1981 Bulletin, p. 1068)

\section{Far Members Only.... wear it with pride!

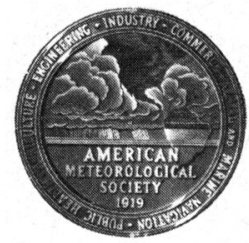

Due to the many requests over the years from members and AMS Chapters, the AMS is offering a very attractive lapel pin/tie tack combination to its members. The Seal of the American Meteorological Society is masterfully reproduced and die-struck on the finest jeweler's metal with a polished Hamilton Gold-clad finish. The size is $\frac{\mathbf{3}^{\prime \prime}}{\mathbf{4}}$ in diameter.

Because of the limited supply, we suggest that you order your AMS lapel pin/tie tack combination now.

$$
\$ 6.00
$$

\section{AMERICAN METEOROLOGICAL SOCIETY}

45 Beacon St. Boston, MA 02108 


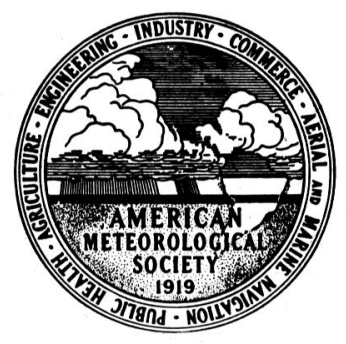

Tropical cyclones and hurricanes, long feared for the death and destruction that often accompanies them, are among the most fascinating of atmospheric phenomena. Created by thermodynamic processes, they unleash vast amounts of energy and influence a wide variety of natural processes along their paths.

In Tropical Cyclones-Their Evolution, Structure and Effects, the author, Richard A. Anthes, tells the story of their creation and destruction, of meteorology's successes in understanding, modeling and predicting their behavior, and of the attempts to modify them.

\section{TROPICAL CYCLONES} Their Evolution, Structure and Effects by Richard A. Anthes

A unique feature of this book, which may be used in the home, laboratory, or classroom, is a thorough treatment of the interactions between storm and ocean, with both observations and theory being integrated to provide a complete description.

Chapter Topics Include:

- Structure and Life Cycle of Tropical Cyclones

- Physical Processes in Tropical Cyclones

- Simulation of Tropical Cyclones by Numerical Models

- Hurricane Modification

- Oceanic Response to Tropical Cyclones

- Tropical Cyclone Forecasting
208 Pages

11 Pages of References

17 Photos, 99 Figures

Hardcover

ISBN: 0-933876-54-8

ISSN: 0065-9401

$\$ 30$ AMS Members

$\$ 40$ Nonmembers

(plus \$2 postage/handling)

Send order and remittance to:

\section{AMERICAN METEOROLOGICAL SOCIETY}

45 Beacon St.

Boston, Mass. 02108 